\title{
Kan zikavirus utløse Guillain-Barrés syndrom?
}

\section{6 av 68 pasienter med Guillain-}

Barrés syndrom i Colombia hadde tegn på gjennomgått zikavirusinfeksjon.

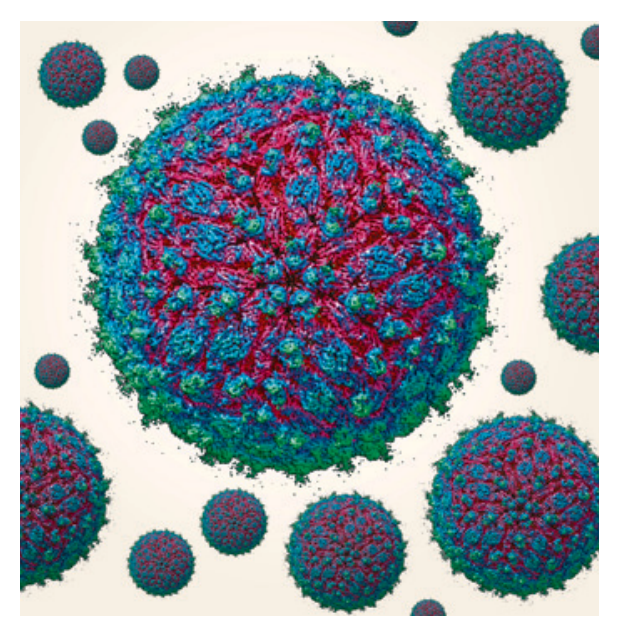

Molekylær modell av zikaviruspartikler. Foto: Science Photo Library
Zikaviruset finnes nå i nesten hele Colombia. I en studie ved seks sykehus ble 68 pasienter med Guillain-Barrés syndrom undersøkt klinisk, og hos 42 av dem ble det gjort virusdiagnostikk i blod, urin og spinalvæske (1). 66 pasienter $(97 \%)$ hadde symptomer forenlig med zikavirusinfeksjon før debut av GuillainBarrés syndrom. Virusdiagnostikk med RTpolymerasekjedereaksjon var positiv for zikavirus hos 17 av 42 testede (40\%), men negativ for denguevirus hos alle de testede.

Median varighet fra symptomstart for virusinfeksjon til det var symptomer på GuillainBarrés syndrom var syv dager. Akutt inflammatorisk demyeliniserende polynevropati ble påvist ved nerveledningsstudier og elektromyografi hos 36 av 46 pasienter (78\%).

- Dette er en svært interessant studie, sier Kristin Ørstavik, som er overlege ved Nevrologisk avdeling, Oslo universitetssykehus. - Funnene støtter hypotesen om at infeksjon med zikavirus kan utløse akutte inflammatoriske polynevropatier. Vanligvis har GuillainBarrés syndrom assosiert med infeksjon en postinfeksiøs start. Mange av pasientene i
Colombia hadde fortsatt symptomer på en pågående virusinfeksjon da de fikk diagnostisert Guillain-Barrés syndrom, de nevrologiske symptomene hadde med andre ord en parainfeksiøs start, sier hun.

- Ved et utbrudd av zikavirus i Fransk Polynesia i 2013 og 2014 ble det også påvist økt forekomst av Guillain-Barrés syndrom, hovedsakelig av subtypen akutt motorisk aksonal nevropati. De fleste pasientene i Colombia hadde derimot en demyeliniserende form for akutt nevropati. Dette er en spennende observasjon som blir interessant å følge i eventuelle nye studier, sier Ørstavik.

\section{Kari Tveito \\ Tidsskriftet}

Litteratur
1. Parra B, Lizarazo J, Jiménez-Arango JA et al. Guillain-Barré Syndrome Associated with Zika Virus Infection in Colombia. N Engl J Med 2016; 375: $1513-23$.

\section{Kan nevrodegenerativ sykdom overføres ved blodoverføring?}

\author{
Parkinsons sykdom og Alzheimers sykdom overføres ikke ved trans- \\ fusjon av blodprodukter. Det viser en ny svensk-dansk studie.
}

Creutzfeldt-Jakobs sykdom, en nevrodegenerativ lidelse kjennetegnet av opphopning av ødelagte proteiner i sentralnervesystemet, kan spres ved blodtransfusjon. Kan dette skje med andre nevrodegenerative lidelser, slik som Parkinsons sykdom og Alzheimers sykdom?

Svenske og danske registre for blodtransfusjoner er nylig brukt for å teste denne hypotesen (1). Studien omfattet rundt 1,5 millioner personer som fikk blodtransfusjon i perioden 1968-2012. Av disse mottok 2,9\% blodprodukter fra en donor som enten ved eller etter transfusjonstidspunktet fikk diagnostisert en nevrodegenerativ lidelse (Parkinsons sykdom, Alzheimers sykdom eller demens av ukjent årsak). Det ble ikke funnet noen signifikant økt risiko for å utvikle noen av disse sykdommene hos dem som fikk overført blodprodukter.

- Denne studien med sine robuste statistiske analyser gir ikke belegg for å hevde at lidelser som Alzheimers sykdom, Parkin- sons sykdom eller generell demens overføres ved transfusjon av blodprodukter, sier Nenad Bogdanovic, som er professor ved Geriatrisk avdeling, Oslo universitetssykehus. - Dette er godt nytt for dem som har fătt blodprodukter fra slike donorer, sier han.

- Vi kan likevel ikke helt utelukke muligheten for at demens overføres gjennom transfusjon av blodprodukter. Derfor trengs det en prospektiv, kontrollert studie med oppfølging og tidlig diagnose av nevrodegenerative sykdommer og analysering av de patologiske proteinene $\mathrm{i}$ hjerne og blod som kjennetegner slike lidelser, sier Bogdanovic.

\section{Kaveh Rashidi}

Tidsskriftet

\footnotetext{
Litteratur

1. Edgren G, Hjalgrim H, Rostgaard K et al. Transmission of Neurodegenerative Disorders Through Blood Transfusion: A Cohort Study. Ann Intern Med 2016; 165: 316-24
}

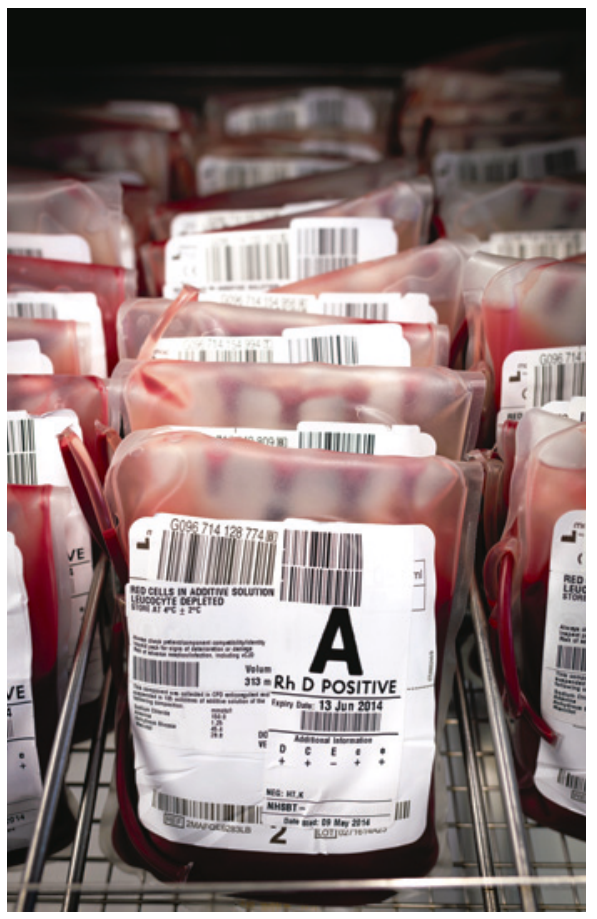

Illustrasjonsfoto: Science Photo Library 